\title{
Diffusion-weighted MR imaging of mediastinal lymphadenopathy
}

\author{
Ali Kemal Sivrioglu 1
}

Received: 6 September 2015 / Accepted: 20 October 2015 / Published online: 3 November 2015

(C) Japan Radiological Society 2015

We have read the interesting article by Razek et al., "Diffusion-weighted MR imaging of mediastinal lymphadenopathy in children," which was published in the August 2015 issue of the journal [1]. The study included fairly important information that was very useful for us. However, I would like to make a contribution.

The authors make the following statement in the discussion section of the article: "Lymph node calcifications can also be found in patients with tuberculosis and sarcoidosis, however, and are expected to have lower ADC values because of possible restricted water movement in the presence of calcification." However, the calcifications in the tissue lead to a change in the texture signal rather than diffusion limitations. A less well-known phenomenon is termed the 'T2-blackout effect' in which calcifications are hypointense on T2-weighted imaging [2]. These calcifications are equally hypointense on DWI and ADC maps. I wanted to clarify this issue.

\section{Compliance with ethical standards}

Conflict of interest The author declares that he has no conflict of interest.

\section{References}

1. Razek AAKA, Gaballa G, Elashry R, Elkhamary S. Diffusionweighted MR imaging of mediastinal lymphadenopathy in children. Jpn J Radiol. 2015;33(8):449-54.

2. Dhanda S, Thakur M, Kerkar R, Jagmohan P. Diffusion-weighted imaging of gynecologic tumors: diagnostic pearls and potential pitfalls. RadioGraphics. 2014;34:1393-416.
Ali Kemal Sivrioglu

draksivrioglu@gmail.com

1 Department of Radiology, Kasimpasa Military Hospital, Istanbul, Turkey 